\title{
Microbiostratigrapy of the Paleocene-Lower Eocene Sequences in the Bibi Hakimeh 2 Subsurface Section Located in the SW of Iran
}

\author{
Fatemeh Moradian', Darioush Baghbani2 ${ }^{*}$, Mohsen Allameh ${ }^{3}$ \\ ${ }^{1}$ Department of Geology, Science and Research Branch, Islamic Azad University, Tehran, Iran \\ ${ }^{2}$ Department of Geology, Damavand University, Damavand, Iran \\ ${ }^{3}$ Department of Geology, Mashhad Branch, Islamic Azad University, Mashhad, Iran \\ Email: *D.baghbani@gmail.com
}

How to cite this paper: Moradian, F., Baghbani, D. and Allameh, M. (2017) Microbiostratigrapy of the Paleocene-Lower Eocene Sequences in the Bibi Hakimeh 2 Subsurface Section Located in the SW of Iran. Open Journal of Geology, 7, 147-161.

https://doi.org/10.4236/ojg.2017.72010

Received: August 24, 2016

Accepted: February 21, 2017

Published: February 24, 2017

Copyright (C) 2017 by authors and Scientific Research Publishing Inc. This work is licensed under the Creative Commons Attribution International License (CC BY 4.0).

http://creativecommons.org/licenses/by/4.0/

\begin{abstract}
This paper investigates the biostratigraphy of the Palaeocene-Lower Eocene sequences in the Bibi Hakimeh 2 subsurface/subterranean sections located in the Bibi Hakimeh Oil Field. The Palaeocene-Lower Eocene sequences are induced as part of the Pabdeh Formation. They are $49 \mathrm{~m}$ in thickness and are made up of clayey limestone with chert intercalations. Biostratigraphic investigations identified 10 genera and 51 species of Planktonic Foraminifera which with respect to the specific planktonic species and according to the newest Wade Biozonation led to the determination of 9 biozones and 4 subzones. The Palaeocene-Early Eocene biostratigraphic boundary determined previously in accordance with the Wynd Biozonation was reviewed with respect to the new biozonation. Moreover, the impression of the PETM on the Planktonic Foraminifera found in the Bibi Hakimeh subsurface section, has been occurred at $\mathrm{P} / \mathrm{E}$ boundary on global scale was studied. Based on this research we can conclude the $\mathrm{P} / \mathrm{E}$ biostratigraphic boundary border is occurred ranges between 2125 - 2124 meters in Pabdeh formation.
\end{abstract}

\section{Keywords}

Pabdeh Formation, Planktonic Foraminifera, Bibi Hakimeh, PETM

\section{Introduction}

The Zagros Orogenic Belt is located in the middle section of the Himalayan Alps Mountain range [1]. This orogeny is the result of the convergence of the continental fragments of central Iran and the Arabian Plate formed as a result of the destruction of the Young Tethys Ocean [2]. Commencement of the continental 
rift at the Permian era and its reactivation during the Triassic age led to the formation of the said ocean. This tectonic incident resulted in the separation of the central Iran Plateau from the Gondwana supercontinent, of which it had been a part and subsequently the Young Tethys Ocean was enclosed by the subduction, obduction, and continental impact processes. The Zagros Orogeny, similar to most orogenies, comprises an internal part (the Sannadj-Sirjan Region) and the external part (the Zagros Fold-Thrust Belt) [2] [3]. The Zagros Fold-Thrust Belt is situated on the northeastern edge of the Arabian platform and consists of Phanaerozoic sedimentary fold sections of $10 \mathrm{~m}$ in thickness [2] [4]. The Palaeocene and Eocene deposits on this section of the Zagros region consist of the Pabdeh Formation which transforms into the Jahrom Formation in an interfingering form, and the TalehZang, Amiran, Shahbazen and Sachoun Formations [5].

\section{Literature Review}

A host of studies have been carried out on the Cenozoic era and specifically on the Palaeogene period. Wynd [6] investigated the Triassic to Miocene sequences of the Zagros region and determined the first bionization based on the specified microfossils and subsequently separated and coined names for these sequences. He believed that only the Palaeocene sediments in the Lorestan region were complete. James \& Wynd [7] investigated the Zagros zone from a biostratigraphical viewpoint and presented 38 formations for the Triassic period to the Quaternary era. They named the Palaeocene and Eocene dolomite deposits of the Fars region as Jahrum Formation while the shale and lime deposits of the same periods in the Fars region were called Pabdeh Formation. They also referred to the same deposits of the Palaeocene to Oligocene and Miocene eras in the Lorestan and Khuzestan regions as the Pabdeh Formation (Figure 1). Kalantari [8] studied various microscopic facies in the Zagros region including the Pabdeh Formation and presented its specific microfossils and subsequently determined the age of the Pabdeh Formation as Palaeocene to Oligocene. Motiei [4] conducted extensive research on stratigraphy of the Zagros region and identified the fossil and lithological properties of the formations of this zone.

\section{Geological Setting}

Biostratigraphic characteristics of the Bibi Hakimeh 2 subsurface/subterranean sections located in the Bibi Hakimeh Oil Field have been investigated in this paper. Bibi Hakimeh Oil Field is situated in the Kohkiloyeh \& Boierahmad Province, in the central region of the city of Gachesaran. $70 \mathrm{~km}$ in length and $5 \mathrm{~km}$ in width, the field is located in the southwestern region of Iran, $210 \mathrm{~km}$ southeast of Ahwaz on the southern region of the Gachesaran Oil Filed (Figure 2). The Bibi Hakimeh subsurface/subterranean section is located at $50^{\circ} 24^{\prime} 36^{\prime \prime} \mathrm{E}$ and $30^{\circ} 07^{\prime} 24^{\prime \prime} \mathrm{N}, 29 \mathrm{~km}$ from the city of Sardasht on Dogonbadan-Genaaveh asphalt 


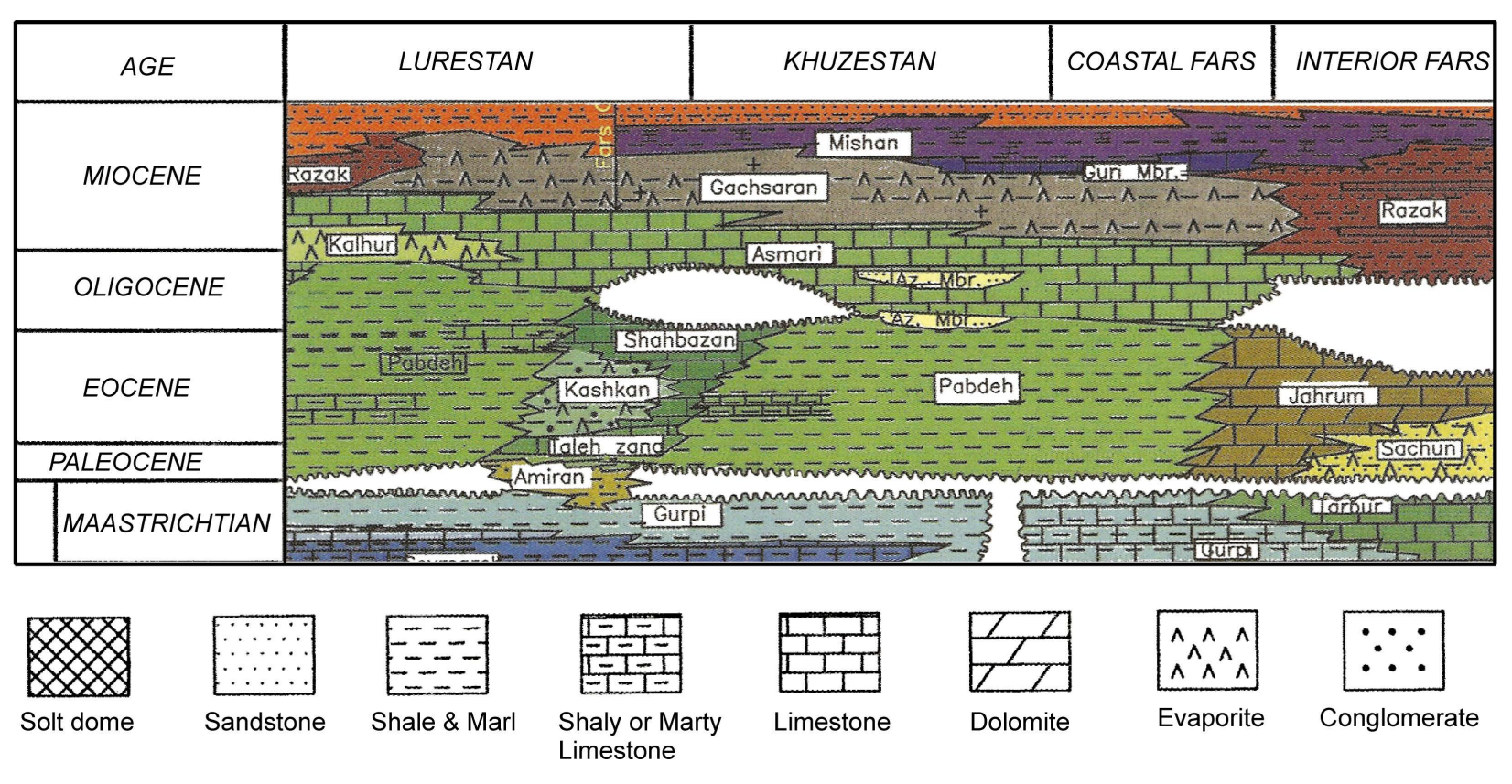

Figure 1. Cenozoic stratigraphy of the Zagros basin, Motiei [4].

road.

\section{Scope of Work}

- Study of the Palaeocene and Eocene lithostratigraphic deposits (Pabdeh Formation).

- Study of the biostratigraphy and identification of the specific microfossils and determination of new biozonations in by the aid of the microfossils.

- Comparison of new biozonations with extensive older biozonations and transformation of the Palaeocene-Eocene boundary on this basis.

\section{Methodology}

The research is divided into two sections:

Laboratorial and Library-Based

In the laboratorial part, 150 microscopic thin-sections prepared by the Oil Company, were studied using PLM, Polarised Light Microscope. The cross-sections were examined from a fossil content viewpoint and the biozonation of the Bibi Hakimeh subsurface/subterranean section was determined through the identification of the specific microfossils, their appearance/shape, emergence and decline period. Various sources such as Postuma [9], Loeblich and Tappan [10], Olsson [11], Berggren [12], Berggren and Pearson [13], Payros [14], Wade [15] were employed in the identification of the foraminifera's microfossils. The latest Wade [15] Biozonation was used in the determination of the biozonation and was compared with the older Wynd [6] version performed on the Pabdeh Formation. 


Sanandaj-Sirjan Zone (SSZ)
$\begin{array}{lll}\text { Marginal Sub zone Late Jurassic- } \\ \text { Early Cretaceous Volcanic (MJKV) }\end{array}$
$\begin{array}{lll}\text { BFZ: Balarud Fault Zone } & \text { KFZ: Kazrum Fault Zone } & \text { MFF: Main Zagros Thrust } \\ \text { (WAEV) } & \text { Urumieh-Dokhtar Eocene Volcanic } \\ \text { HZF: High Zagros Fault } & \text { TF: Tabriz Fault } & \text { MFF: Main Frontal Fault }\end{array}$

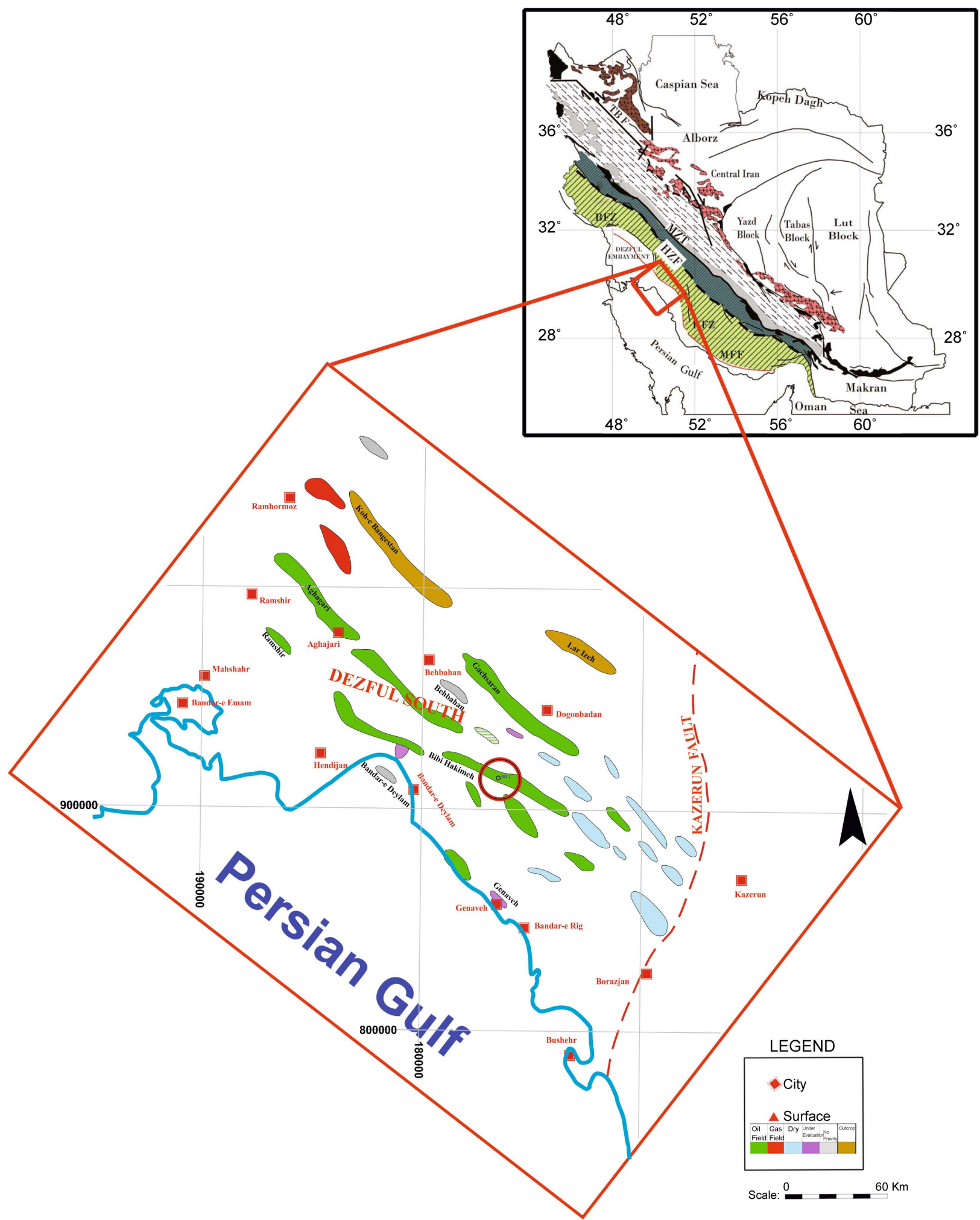

Figure 2. Geographical and geological map of the study area, modified from geological and exploration, Tehran, 1969. 


\section{Lithology}

Investigation of the peaks of the gamma and sonic waves alongside inspection of the cuttings produced within drilling operation indicates that the depositional sequence in this well consists of the Fars group of deposits, Asmari Formation limestones, marl and limey clay replete with cherts of Pabdeh Formation, clayey limestones replete with chert, and Gurpi Formation marl, and Bangestan sequence group in a top-down direction. This sequence is $1310 \mathrm{~m}$ in thickness. Palaeocene and lower Eocene deposits, and clayey limestones including chert interlayers are indicative of the Paabdeh Formation. This formation has a thickness of $298 \mathrm{~m}$ in this well. The upper boundary of this formation is contiguous with the Oligocene-aged Asmari Formation while its lower boundary is contiguous with the Paabdeh Formation. The Palaeocene and lower Eocene deposits of the Paabdeh Formation in the Bibi Hakimeh-2 well have a thickness of $49 \mathrm{~m}$ and in a topdown direction including:

$49 \mathrm{~m}$ of clayey limestone alongside chert interlayers (Figure 3 ).

\section{Micro-Biostratigraphy}

Study of the Palaeocene and Lower Eocene depositional microfossils in the Bibi Hakimeh subsurface/subterranean section, revealed 10 genera and 51 species of Planktonic Foraminifera, 9 genera and species of benthic foraminifera, and 1 non-foraminifera form. The latest Wade Biozonation was employed in this research and was compared with the older Wynd [6] version performed on the Pabdeh Formation. 9 biozones and 4 sub-biozones were identified according to
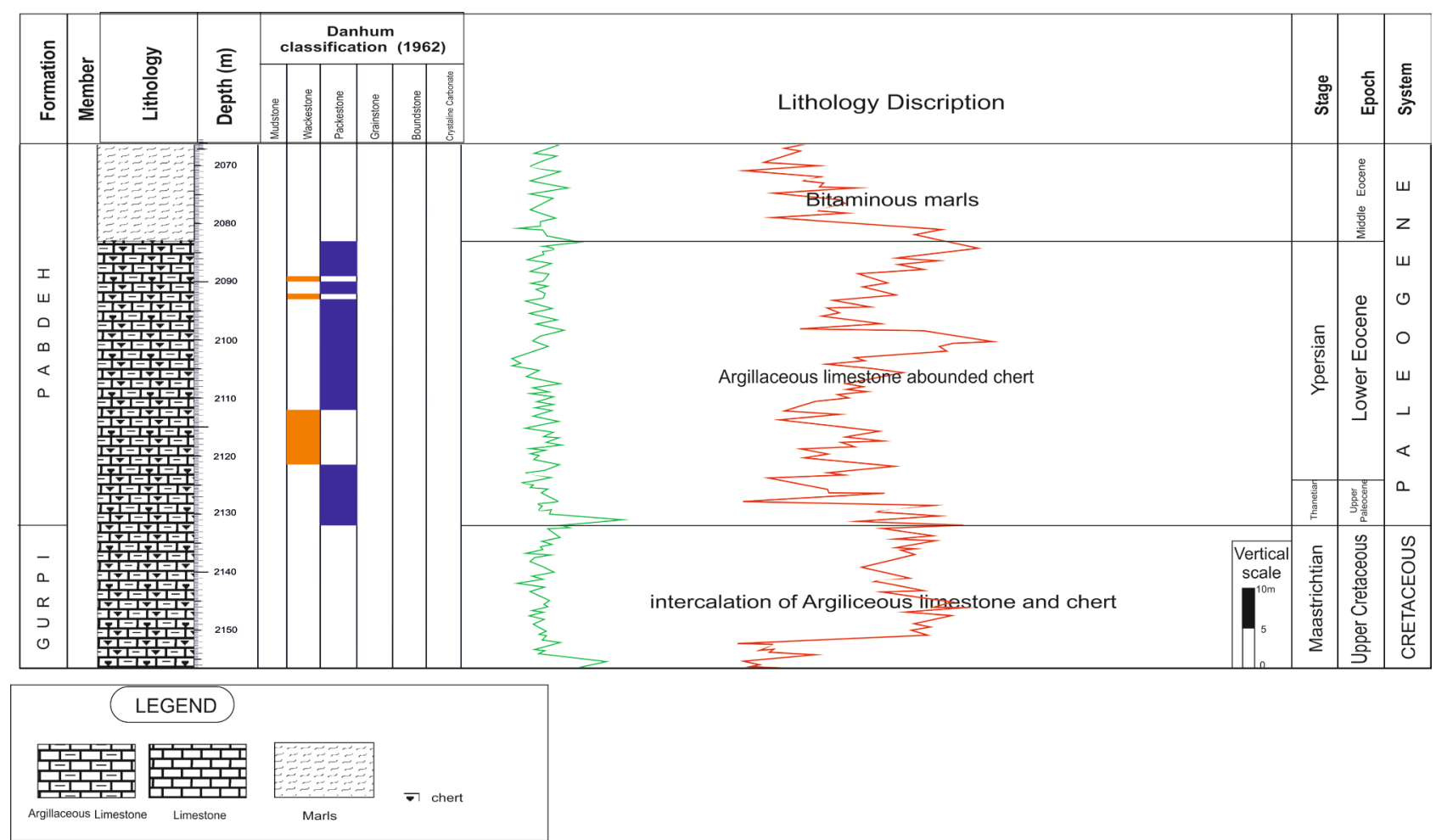

Figure 3. Lithostratigraphy column of Bibi Hakimeh subsurface/subterranean section, Bourgeois [16]. 
Wade [15]:

\section{Zone P4. Globanomalinapseudomenardii Taxon-Range Zone}

This biozone has been determined according to the domain of the Globanomalinapseudomenardii species [12]. The resource of this biozone does not lie within this section although its end is identifieddetermined by the disappearance of the above species at a depth of $2125 \mathrm{~m}$. This biozone was dated Middle-Late Palaeocene (Thanetian). This biozone includes three subzones of which the P4a subzone was not identified in this section.

P4b. Acarinina subsphaerica Subzone (partial-range-subzone)

This subzone is of the partial-range type and covers the distance/interval between the highest occurrence, Parasubbotinavariospira (HO) and the lowest occurrence of Acarininasoldadoensis (LO) [12]. In the Bibi Hakimeh section, the lower boundary of this subzone does not fall within the said section due to absence of the Parasubbotinavariospira species and the lowest occurrence at a depth of $2130 \mathrm{~m}$ is identified as its upper boundary. The age of this subzone is determined as late Paleocene (Thanetian) according to the biozone defined by Wade, comparison and conformation with the same subzone and its fossil complex. The fossil complex concomitant with this zone includes:

Acarinina sp., Acarinina nitida, Morozovellaapanthesma, Acarinina subsphaerica, Subbotina triangularis, Igorinatadjikistanensis, Igorina pusilla, Morozovella velascoensis, Igorinaalbeari, Morozovellaacutispira, Morozovellaconicotruncata, Morozovella angulate, Globanomalinapseudomenardii, Subbotina velascoensis, Morozovella acuta.

P4c. Acarinina soldadoensis Globanomalinapseudomenardii Subzone (concurrent-range-subzone)

This subzone is of the concurrent-range zone type and covers the interval between the lowest occurrence, of Acarininasoldadoensis (LO) and the highest occurrence of Globanomalinapseudomenardii (HO) [12]. In the Bibi Hakimeh section, the lower boundary of this subzone was identified at a depth of $2130 \mathrm{~m}$ with the lowest occurrence of Acarininasoldadoensis as the lower boundary while the highest occurrence of the Globanomalinapseudomenardii at a depth of 2125 was recognized as its upper boundary. The age of this subzone is determined as Late Palaeocene (Late Thanetian) according to the biozone defined by Wade, comparison and conformation with the same subzone and its fossil complex. The fossil complex concomitant with this zone includes:

Globanomalinapseudomenardii, Acarinina soldadoensis, Morozovella aequa, Acarininaesnaensis, Acarininacoalingensis, Acarinina decepta, Subbotina velascoensis, Morozovella acuta, Acarinina sp., Acarinina nitida, Morozovella velascoensis, Igorinaalbeari.

Zone P5. Morozovella velascoensis Partial-Range Zone (partial-rangezone)

This subzone is of the partial-range zone type and covers the distance between the the highest occurrence of Globanomalinapseudomenardii (HO) and lowest occurrence, of Acarininasibaiyaensis (LO) [12]. In the Bibi Hakimeh section, the 
lower boundary of this subzone was identified at a depth of $2125 \mathrm{~m}$ with the highest occurrence of Globanomalinapseudomenardii as the lower boundary while the highest occurrence cannot be determined due to the lack of identification of the Acarininasibaiyaensis species.

Zone E1. Acarininasibaiyaensis Lowest-Occurrence Zone (lowest-occurrence-zone)

This subzone is of the lowest-occurrence zone type and covers the interval between the lowest occurrence of Acarininasibaiyaensis (LO) and the highest occurrence of Pseudohastigerinawilcoxensis (LO) [13]. In the Bibi Hakimeh section, the lower boundary of this biozone cannot be determined due to the lack of identification of the Acarininasibaiyaensis species. The upper boundary was determined at a depth of $2124 \mathrm{~m}$ with the lowest occurrence of Pseudohastigerinawilcoxensis.

The boundary between the E1 \& P5 biozones in the Bibi Hakimeh section is indistinguishable. Therefore, the age of the span between the lower boundary of the P5 biozone at $2125 \mathrm{~m}$ and the upper boundary of the E1 biozone at a depth of $2124 \mathrm{~m}$ is determined to be Late-Paleocene to Early Eocene (Latest ThanetianSparnacian).

Zone E2. Pseudohastigerinawilcoxensis/Morozovella velascoensis Concurrent-Range Zone

This subzone is of the concurrent-range zone type and covers the interval between the lowest occurrence of Pseudohastigerinawilcoxensis (LO) and the highest occurrence of Morozovella velascoensis (HO) [13].

In the Bibi Hakimeh section, the lower boundary of this biozone was determined as the lowest occurrence of Pseudohastigerinawilcoxensis at a depth of $2124 \mathrm{~m}$ while the upper boundary was established to be the highest occurrence of Morozovella velascoensis at a depth of $2115 \mathrm{~m}$. The age of this zone is determinedas early Eocene (Sparnacian) according to the biozone defined by Wade, comparison and conformation with the same subzone and its fossil complex. The fossil complex concomitant with this zone includes (Figure 4):

Acarininasoldadoensis, Morozovella aequa, Acarininaesnaensis, Acarininacollectea, Acarinina decepta, Subbotina velascoensis, Morozovella acuta, Acarinina intermedia, Acarininaaquensis, Morozovella velascoensis, Igorinaconvexa, Subbotinainaquispira, Morozovella gracilis, Pseudohastigerinawilcoxensis.

\section{Zone E3. Morozovella velascoensis Partial-Range Zone}

This subzone is of the partial-range zone type and covers the interval between the highest occurrence of Morozovella velascoensis (HO) and the lowest occurrence of Morozovella formosa (LO) [13].

In the Bibi Hakimeh section, the lower boundary of this biozone was determined as the highest occurrence of Morozovella velascoensis at a depth of $2115 \mathrm{~m}$ while the upper boundary was established to be the highest occurrence of Morozovella formosa at a depth of $2113 \mathrm{~m}$. The age of this zone is determined as early Eocene (Ypresian) according to the biozone defined by Wade, comparison and conformation with the same subzone and its fossil complex. The fossil complex 

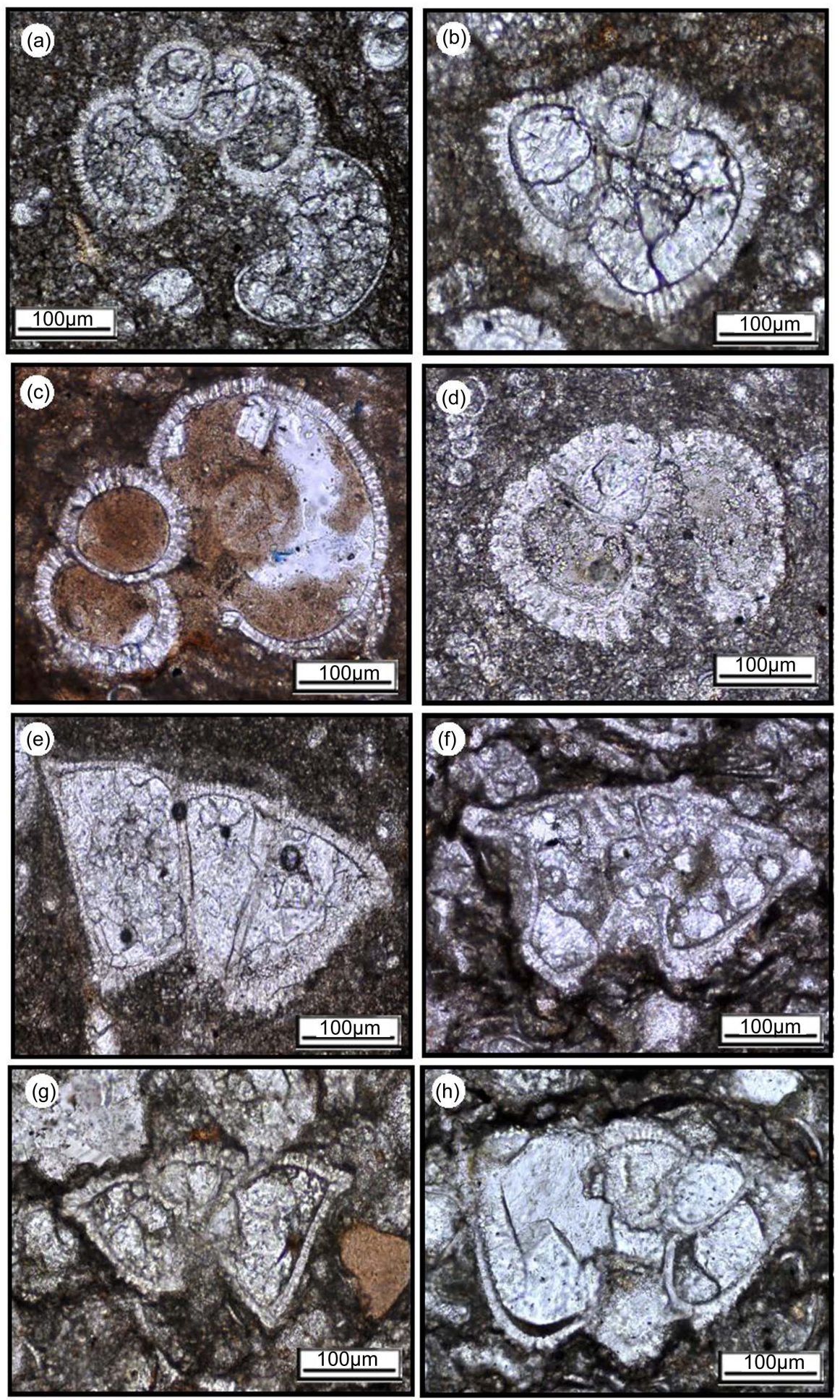

Figure 4. a) Acarininaaquiensis [17], b) Acarininabullbrookii [18], c) Turborotalia frontosa [19], d) Acarininacoalingensis [20], e) Morozovella caucasica [21], f) Morozovella formosa [21], g) Morozovella gracilis [22], h) Morozovellasubbotinae [23].

concomitant with this zone include:

Acarininaaquiensis, Igorinaconvexa, Morozovella gracilis, Morozovella subbotinae, Acarininacoalingensis, Morozovella aequa. 


\section{Zone E4. Morozovella formosa Lowest-Occurrence Zone}

This zone is of the lowest-occurrence type and covers the distance between the lowest occurrence of Morozovella formosa (LO) and the highest occurrence of Morozovella aragonensis (HO) [13].

In the Bibi-Hakimeh section, the lower boundary of this biozone was determined as the lowest occurrence of Morozovella formosa at a depth of $2113 \mathrm{~m}$ while the upper boundary was established to be the highest occurrence of Morozovella aragonensis at a depth of $2101 \mathrm{~m}$. The age of this zone is determined as early Eocene (Ypresian) according to the biozone defined by Wade and comparison and conformation with the same subzone and its fossil complex. The fossil complex concomitant with this zone include:

Acarinina primitiva, Morozovellalensiformis, Acarinina pseudotopilensis, Acarinina decepta, Acarininaesnaensis, Morozovella aequa, Morozovella subbotinae, Subbotinainaquispira, Pseudohastigerinawilcoxensis, Morozovella gracilis.

Zone E5. Morozovella aragonensis/Morozovella subbotinae ConcurrentRange Zone

This zone is of the lowest-occurrence zone type and covers the interval between the lowest occurrence of Morozovella aragonensis (LO) and the highest occurrence of Morozovella subbotinae (HO) [13].

In the Bibi Hakimeh section, the lower boundary of this biozone was determined as the lowest occurrence of Morozovella aragonensisa at a depth of 2101 $\mathrm{m}$ while the upper boundary was established to be the highest occurrence of Morozovella subbotinae at a depth of $2093 \mathrm{~m}$. The age of this zone is determined as early Eocene (Ypresian) according to the biozone defined by Wade, comparison and conformation with the same subzone and its fossil complex. The fossil complex concomitant with this zone includes:

Acarinina primitiva, Pseudohastigerinawilcoxensis, Acarinina pseudotopilensis, Morozovella caucasica, Dentoglobigerinayeguaensis, Acarinina pentacamerata, Morozovella crassata, Morozovella aragonensis, Acarininaaquiensis, Acarininacoalingensis, Globigerinathekasp, Acarininabullbrooki, Acarininagraveli, Acarinina decepta, Acarininaesnaensis, Subbotinainaquispira, Igorinaconvexa.

\section{Zone E6. Acarinina pentacamerata Partial-Range Zone}

This subzone is of the partial-range zone type and covers the interval between the highest occurrence of Morozovella subbotinae (HO) and lowest occurrence of Acarininacuneicamerata (HO) [13].

In the Bibi Hakimeh section, the lower boundary of this biozone was determined by the highest occurrence of the Morozovella subbotinae at a depth of 2093 m. The upper boundary cannot be established due to the non-recognition of Acarininacunicamerata.

\section{Zone E7. Acarininacuneicamerata Lowest-Occurrence Zone}

This biozone is of the lowest-occurrence zone type and covers the interval between the lowest occurrence of Acarininacuneicamerata (LO) and the highest occurrence of Guembelirioidesnuttali (HO) [14]. This biozone has been dated Early Eocene and Middle Eocene. This biozone is divided into the following 
subzones:

\section{Subzone E7a Acarininacuneicamerata Lowest-Occurrence Zone}

This zone is of the lowest-occurrence zone type and covers the interval between the lowest occurrence of Acarininacuneicamerata (LO) and the lowest occurrence of Turborotalia frontosa (LO) [14].

The lower boundary of this biozone cannot be determined in the Bibi Hakimeh section due to the non-recognition of the Acarininacuneicamerata species while the upper boundary was determined by the lowest occurrence of the Turborotalia frontosa at a depth of $2086 \mathrm{~m}$. The boundary between the E6 \& E7a cannot be established on this basis; therefore, the same biozones were determined for the depths of 2093 to $2086 \mathrm{~m}$. The age of this zone is determined as early Eocene (Ypresian) according to the biozone defined by Wade, comparison and conformation with the same subzone and its fossil complex.

The fossil complex concomitant with this zone includes:

Acarininacoalingensis, Acarininacollectea, Acarinina intermedia, Acarinina interposita, Acarinina pentacamerata, Dentoglobigerinayeguaensis.

\section{Subzone E7b. Turborotalia frontosa Lowest-Occurrence Zone}

This zone is of the lowest-occurrence zone type and covers the interval between the lowest occurrence of Turborotalia frontosa (LO) and the lowest occurrence of Guembelitrioidesnuttalli (LO) [14]. In the Bibi Hakimeh section the lower boundary of this biozonewas determined by the lowest occurrence of the Turborotalia frontosa species at a depth of $2086 \mathrm{~m}$ while the upper boundary is established by the lowest occurrence of the Guembelitrioidesnuttalli of the Middle Eocene age though it does not fall within the study area. Therefore, the age of this subzone is determined to be Early-Middle Eocene according to the fossil complex. The fossil complex concomitant with this zone includes:

Acarininacoalingensis, Acarininacollectea, Acarinina intermedia, Acarininaprimitiva, Acarinina interposita, Acarininabullbrooki, Acarinina pentacamerata, Dentoglobigerinayeguaensis, Turborotalia frontosa, Chilloguembelina sp., based on Planktonic Foraminifera while 2 biozones were classified according to Wynd [6].

Morozevella velascoensis-Globanomalina pseudo menardii Zone (assemblages-zone)

This biozone defined by Wynd [6] is referred to as zone number 42 and is determined by the occurrence of the Morozovella velascoensis and Globanomalina pseudo menardii species at a depth of $2132 \mathrm{~m}$. The upper boundary of this biozone is established by the last occurrence of Morozovella velascoensis at a depth of $2115 \mathrm{~m}$. The age of this zone is determined as Late Paleocene according to the biozone (No. 42) defined by Wynd \& comparison and conformation.

Morozevella subbotinae-Morozovella Formosa Morozovella aragonensis Zone

This zone referred to as zone Number 45 [6] comprises the abovementioned fossil complex and is located at the upper occurrence boundary of Morozovella velascoensis and the lower occurrence boundary of Morozovella spinulosa \& 
Hantkenina $s p$. It is determined by the last occurrence of the Morozovella velascoensis at a depth of $2115 \mathrm{~m}$ as the lower boundary of the biozone and the first occurrence of Hantkenina sp. at a depth of $2083 \mathrm{~m}$. The age of this zone is determined as Late Eocene according to the biozone (No. 45) defined by Wynd \& comparison and conformation.

Comparison and conformation of the Wade [15] biozonation with the oldest Wynd [6] Biozonation indicates that the Paleocene-Early Eocene biostratigraphic boundary, which according to the Wynd [6] Biozonation, had been located at the boundary of the biozone numbers $42 \& 45$ at $2115 \mathrm{~m}$ from the base of the formation, is transferred to the boundary between biozones P5 \& E1 at a interval of 2124 to $2125 \mathrm{~m}$ according to the Wade Biozonation (Figure 5).

Comparing superimposition at the Wade [15] Biozonation with the oldest Wynd [6] Biozonation proves that the biostratigraphic boundary at Paleoceneearly Eocene in the Bibi Hakimeh subsurface/subterranean section the which is carried out based on the Wynd Biozonation [6] is located between the two biozones at 42, 45 was marked by the presence at Morozovella velascoensis at 2115 meter all the base of the formation. On the very other mind, through comparing the Wade Biozonation [15] with the lost presence of Globanomalinapseudomenardii aged late Paleocene at 2125 meter cum the first occurrence of Pseudohastigerinawilcoxensis aged early Eocene at 2124 all the base of the formation, serving as the boundary at $\mathrm{P} / \mathrm{E}$ containing two biozones at P5, E1.

The PETM is also applied to separate the P/E boundary cum the phenomenon at emergence, eptinction at index foraminifera [24]. The global warming has been deemed, short term climatic event which took place 55.5 milion years earlier [24] [25]. The event of the P/E boundary is marked by significant enormous carbon exchanges that were once occurred on global scale, led to shifts in various phenomena like, 5 - 7 warming or temperature increase, extinction of the entire bentic foraminifera, upheaval in the cammunites of Planktonic Foraminifera, quick migration or shift at carbonate balance depth to shallower depth, discernible negative change in CIE carbon isotope trend [26].

In the light of studies conducted by Pardo [27] on the paleoecology of P/E boundary and the impression of PETM on planktonic foraminifera in khazakhestan, cum the studies that Wade [28] has conducted in 2004 on the biostratigraphy, the impresion at PETM on the mechanism of Morozovella genus extinction in the west of the northern atlantic, it can be judged that the event has also left impressions on the subsurface section at the Bibi Hakimeh in SW of Iran at $\mathrm{P} / \mathrm{E}$ boundary. Pardo [27] has classified the foraminifera as for their response to thermal fluctuation, ecologic-bio condition in to two group at cold-water foraminifera (C) which belong to Subbotinid, chilogumbelinid familes, warm-water foraminifera (W) which belong to Morozovellids, Acarininids, Igorinids families. They believe that at contiguity at the boundary, the number, variety of cold-water groups plummet or even disappear to some extent, which is perceived to be the comeuppance of intolerable heat that has compelled them to travel towards higher latitudes, leaving salely behind the warm-water groups who have been capable 


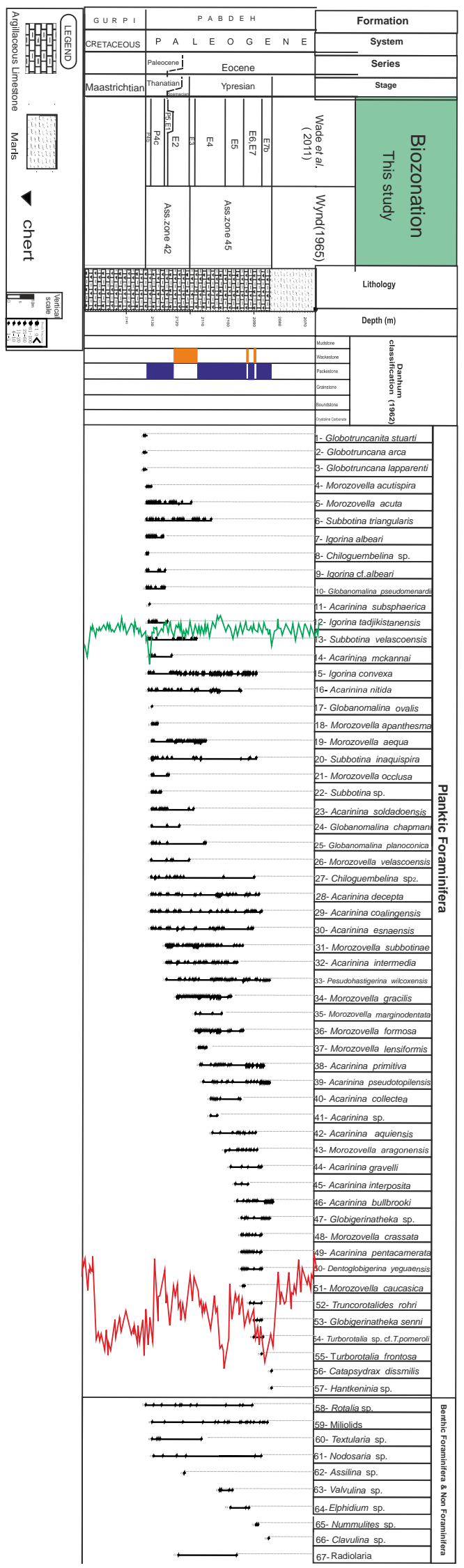

Figure 5. Biostratigraphy column and biozonation of Bibi Hakimeh subsurface section. 
at tolering the heat, all the sudden the variety number of Planktonic Foraminife$\mathrm{ra}$ at the subsurface section at Bibi Hakimeh drops down at 2125 - 2124 meters interval. The cold-water groups suite assemblages Subbotinatrangularis, Subbotinavelascoensis, Chilogumbelina sp. species have had presence from the base of the formation up to the contiguity at the boundary, and however they have disappered all the sudden at 2125 meter from Formation, reappearing at 2124 meter all the base of the formation. Warm-water foraminifera have been identified that belong to Morozovellaacuta, Acarininasoldadoensis, Acarinina nitida are among them. Pardo [27] suggested that the impression at PETM on the Acarininids varies to some degree. Only the species that have had less chambers, less complicated shapes have resisted the heat. Furthermore, species of the more chambers, more angles have developed while kept away from such sudden heat at the Bibi Hakimeh subsurface section, solely the species of Acarininasoldadoensis, Acarinina nitida from the Acarininids who have less chambers, more plain shapes have been identified at 2125 - 2124 meters interval.

\section{Conclusion}

Analysis of the Palaeocene-Lower Eocene sequences of the Paabdeh Formation in the Bibi Hakimeh subsurface/subterranean section resulted in the identification of 10 genera and 51 spices of Planktonic Foraminifera. According to the latest Wade Biozonation and their appearance, emergence and decline of the Planktonic Foraminifera index, 9 biozones and 4 biosubzones were identified which were compared with the oldest biozonation performed on the Paabdeh Formation. On this basis, the Palaeocene-Lower Eocene biostratigraphic boundary, which according to the Wynd Biozonation had been located at the border of the biozone numbers $42 \& 45$ at $2115 \mathrm{~m}$ from the base of the formation, is now situated at the boundary between biozones P5 \& E1 at an interval of 2124 to $2125 \mathrm{~m}$ from the formation base according to the Wade Biozonation. The new Wade Biozonation [15] incorporates P5 \& E1 biozones at 2125 - 2124 meters interval at the base of the formation. More to the point, PETM that has occurred at P/E boundary on global scale affected the Planktonic Foraminifera found in the subsurface section at Bibi Hakimeh, leading to slump in variety number of Planktonic Foraminifera at 2125 - 2124 meters interval. Hence considering the emergence declime at index species based on Wade Biozonation cum the impression at PETM on Planktonic Foraminifera at the aforesaid interval, the P/E biostrtigraphic boundary has been revised, decided at 2125 - 2124 meters interval inside the Pabdeh Formation.

\section{References}

[1] Berberian, M. and King, G.C.P. (1981) Towards a Paleogeography and Tectonic Evolution of Iran. Canadian Journal of Earth Sciences, 18, 210-265. https://doi.org/10.1139/e81-019

[2] Berberian, M. (1995) Master "Blind" Thrust Faults Hidden under the Zagros Folds: Active Basement Tectonics and Surface Morphotectonics. Tectonophysics, 241, 193-224. https://doi.org/10.1016/0040-1951(94)00185-C 
[3] Motiei, H. (1994) Geology of Iran: Stratigraphy of Zagros. Geological Survey of Iran Publication, Tehran, 583.

[4] Motiei, H. (2001) Simplified Table of Rock Units in Southwest Iran. Keyhan Exploration and Production Services, Tehran.

[5] Alavi, M. (2004) Regional Stratigraphy of Zagros Fold-Thrust Belt of Iran and Its Proforel and Evolution. American Journal of Science, 304, 1-20. https://doi.org/10.2475/ajs.304.1.1

[6] Wynd, J.G. (1965) Biofacies of the Iranian Oil Consortium Agreement Area. Iranian Oil Offshore Company Report 1082, Unpublished.

[7] James, G.A. and Wynd, J.G. (1965) Tratigraphic Nomenclature of Iranian Oil Consortium Agreement Area. American Association of Petroleum Geologists Bulletin, 49, 94-156.

[8] Kalantari, A. (1986) Microfacies of Carbonate Rocks of Iran. National Iranian Oil Company, Geological Laboratories, Publication, Tehran, 520.

[9] Postuma, J.A. (1971) Manual of Planktonic Foraminifera, Royal Dutch/Shell Group, the Hange, the Netherland, Elservier, Amsterdam, 420 p.

[10] Loeblich Jr., A.R. and Tappan, H. (2015) Foraminiferal Genera and Their Classification. Springer, Berlin.

[11] Olsson, R.K., Hemleben, C., Berggren, W.A. and Huber, B.T. (1999) Atlas of Paleocene Planktonic Foraminifera. Vol. 85, Smithsonian Institution Press, Washington DC, 1-252. https://doi.org/10.5479/si.00810266.85.1

[12] Berggren, W.A., Aubry, M.P., Van Fossen, M.P., Kent, D.V., Norris, R.D. and Quillevere, F. (2000) Integrated Palaeocene Calcareous Plankton Magnetobiochronology and Stable Isotope Stratighraphy: DSDP Site 384 (NW Atlantic Ocean). Paleogeography, Paleoclimatology, Paleoecology, 159, 1-51.

https://doi.org/10.1016/S0031-0182(00)00031-6

[13] Berggren, W.A. and Pearson, P. (2005) A Revised Tropical to Subtropical Paleogene Planktonic Foraminiferal Zonation. The Journal of Foraminiferal Research, 35, 279298. https://doi.org/10.2113/35.4.279

[14] Payros, A., Bemaola, G., Orue-Etxebarria, G., Dinares-Turell, J., Tosquella, J. and Apellaniz, E. (2007) Reassessment of the Early-Middle Eocene Biomagnetochronology Based on Evidence from the Gorrondatxe Section (Basque Country, Western Pyrenees). Lethaia, 40, 183-195. https://doi.org/10.1111/j.1502-3931.2007.00016.x

[15] Wade, B.S., Pearson, P.N., Berggren, W.A. and Palike, H. (2011) Review and Revision of Cenozoic Tropical Planktonic Foraminiferal Biostratigraphy and Calibration to the Geomagnetic Polarity and Astronimical Time Scale. Earth Science Review, 104, 111-142. https://doi.org/10.1016/j.earscirev.2010.09.003

[16] Bourgeois, E. (1962) Bibi Hakimeh Well. Report 22038, Iranian Oil Operating Company.

[17] Loeblich, A.R.J. and Tappan, H. (1961) The Status of the Foraminiferal Genera Ammodiscus Reuss and Involutina Terquem. Micropaleontology, 7, 189-192. https://doi.org/10.2307/1484277

[18] Bolli, H.M. (1957) The Genera Globigerina and Globorotalia in the PaleoceneLower Eocene Lizard Springs Formation of Trinidad. B.W.L. US. National Musesum Bulltin, 215, 61-81.

[19] Subbotina, N.N. (1953) Fossil Foraminiferas of the USSR: Globigerinidae, Hantkeninidae and Globorotaliidae. Trudy VNIGRI, New Series, 76, 296. (In Russian)

[20] Cushman, J.A. and Hanna, G.D. (1927) Foraminifera from the Eocene near San Diego, California. Transactions of the San Diego. Society of Natural History, 5, 45-64. 
[21] Glaessner, M.F. (1937) Planktonische Foraminiferenaus der Kreide und demEozän und ihrestratigraphische Bedeutung. Studies in Micropaleontology. Vol. 1, Publications of the Laboratory of Paleontology, Moscow University, Moscow, 27-52.

[22] Bolli, H.M. (1957) Planktonic Foraminifera from the Eocene Navet and San Ferando Formation of Trinidad. B.W.L. US. National Musesum Bulltin, 215, 155-172.

[23] Morozova, V.G. (1939) On the Stratigraphy of the Upper Cretaceous and Paleogene of the Emba, Region According to the Foraminiferal Faunas. Moskova. Obshch. Ispytately Prirody Byull. Otdel Geology, 17, 59-86. (In Russian)

[24] Zachos, J.C., Röhl, U., Schellenberg, S.A., Sluijs, A. and Hodell, D.A. (2005) Rapidacidification of the Ocean during the Paleocene-Eocene Thermal Maximum. Science, 308, 1611-1615. https://doi.org/10.1126/science.1109004

[25] Zachos, J.C., Schouten, S., Bohaty, S., Quattlebaum, T. and Sluijs, A. (2006) Extreme Warming of Mid-Latitude Coastal Ocean during the Paleocene-Eocene Thermal Maximum: Inferences from TEX86 and Isotope Data. Geology, 34, 737-740. https://doi.org/10.1130/G22522.1

[26] Zachos, J.C., Dickens, G.R. and Zeebe, R.E. (2008) An Early Cenozoic Perspective on Greenhouse Warming and Carbon-Cycle Dynamics. Nature, 451, 279-283. https://doi.org/10.1038/nature06588

[27] Pardo, A., Keller, G. and Oberhansli, H. (1999) Paleoecologic and Paleoceanographic Evolution of the Tethyan Realm during the Paleocene-Eocene Transition. The Journal of Foraminiferal Research, 29, 37-57.

[28] Wade, B.S. (2004) Planktonic Foraminiferal Biostratigraphy and Mechanisms in the Extinction of Morozovella in the Late Middle Eocene. Marine Micropaleontology, 51, 23-38. https://doi.org/10.1016/j.marmicro.2003.09.001

\section{Submit or recommend next manuscript to SCIRP and we will provide best service for you:}

Accepting pre-submission inquiries through Email, Facebook, LinkedIn, Twitter, etc. A wide selection of journals (inclusive of 9 subjects, more than 200 journals)

Providing 24-hour high-quality service

User-friendly online submission system

Fair and swift peer-review system

Efficient typesetting and proofreading procedure

Display of the result of downloads and visits, as well as the number of cited articles

Maximum dissemination of your research work

Submit your manuscript at: http://papersubmission.scirp.org/

Or contactojg@scirp.org 